\title{
O desafio de publicar um periódico com transdisciplinaridade
}

\section{e convergência de foco}

Cumprindo a premissa de periodicidade definida em nossa política editorial, de veicular um novo número a cada final de trimestre, os CIADS v.4, n.2 - abr./jun. 2015 está disponível para todos aqueles leitores, autores e pesquisadores, cujo interesse pela área do Direito Sanitário seja objeto de reflexão.

Nesse $2^{\circ}$ número do ano, estão presentes temas que apresentam abordagens transdisciplinares, sem perder a convergência com o tema foco do periódico. O primeiro artigo da edição analisa os condicionantes de saúde nos instrumentos de licenciamento ambiental - Estudo de Impacto Ambiental (EIA) e Relatório de Impacto Ambiental (RIMA) no que diz respeito à observância das bases legais e infralegais, tendo como case o licenciamento de empreendimento hidrelétrico no complexo do Rio Madeira (RO). Ainda no viés ambiental de abordagem, Zancul discute os recursos hídricos e o saneamento como direito humano essencial, e a forma como essas questões estão dispostas na Política de Saneamento Básico do Brasil. A autora considera a legislação nacional e os tratados internacionais afetos pra a sua discussão.

Na perspectiva da gestão da saúde, o terceiro artigo aborda a Política Nacional de Atenção Integral às Pessoas com Doenças Raras, por meio da análise das características e preceitos normativos da referida Política, a partir dos elementos percebidos como essenciais na construção e dinâmica de gestão no contexto da saúde. Em 'Estudo das Ações Diretas de Inconstitucionalidade do Programa Mais Médico', Silva e Pacheco analisam as duas Ações Diretas de Inconstitucionalidade propostas junto ao Supremo Tribunal Federal, seus conteúdos e posições jurídico-doutrinárias dos atores envolvidos. No quinto artigo, de autoria de Borges e Moura, a questão dos doentes mentais que cometem condutas delitivas é abordada, sob a perspectiva da avaliação do direito à saúde dos portadores de doença mental, considerados inimputáveis, na produção normativa vigente no Senado Federal, na Câmara Legislativa e no Ministério da Saúde, produzida no período de 2011 a 2014 . Ainda com relação aos instrumentos de gestão, Santos apresenta as questões a serem consideradas, acerca da responsabilidade sanitária, no Contrato Organizativo da Ação Pública da Saúde (COAP), cujo objetivo é unificar e integrar as 
ações dos entes federativos, subsidiárias e complementares, levando em consideração as necessidades da região de saúde, dando ênfase à responsabilização dos gestores da saúde.

Com relação à produção em língua espanhola, essa edição apresenta as reflexões de quatro pesquisadores argentinos, com dois textos que discutem a legislação naquele país. Carignani e Robledo abordam o Sistema de Proteção à Saúde na Argentina, apontando desafios e perspectivas de integração a um cenário internacional, que vise direitos amplamente resguardados e novas formas de financiamento que garantam assegurar limites qualitativos e quantitativos à proteção da saúde daquela população. As autoras Zalazar e Herbas analisam a forma como é feita a proteção aos incapazes, considerando a jurisprudência produzida pela Suprema Corte de Justiça, na Argentina, garantindo o cumprimento de todas as medidas de proteção e promoção da saúde.

Ao final dessa incursão pelo Sumário do v.4, n.2 dos CIADS, reafirmamos o compromisso deste periódico científico com o acesso aberto, como forma de veiculação democrática das informações produzidas pela comunidade acadêmico-científica.

Esperamos que os autores, leitores, revisores, enfim todo o público que participa dos Cadernos estejam conosco, submetendo produções textuais e promovendo o debate da temática do Direito Sanitário com qualidade e diversidade.

Saudações fraternas,

\author{
Incolduque \\ Maria Célia Delduque \\ Editora Científica do CIADS
}

